\title{
ASCITIC INTERLEUKIN 6 AND SERUM PROCALCITONIN FOR EARLY DETECTION OF SPONTANEOUS BACTERIAL PERITONITIS IN ADVANCED LIVER CIRRHOSIS
}

\author{
Marwa Ibrahim Metawea ${ }^{(1)}$, Doaa Ahmed Elwazzan ${ }^{(2)}$, Reham Abdel Haleem Abo Elwafa ${ }^{(3)}$, Sara \\ Lotfy Asser ${ }^{(4)}$ \\ 1) Department Hepatology, Faculty of Medicine, Alexandria University. \\ 2) Department Tropical Medicine, Faculty of Medicine, Alexandria University. \\ 3) Department Clinical Pathology, Faculty of Medicine, Alexandria University. \\ 4) Department Microbiology, Faculty of Medicine, Alexandria University.
}

\begin{abstract}
Background: Liver cirrhosis is associated with frequent bacterial infections that increase mortality. Spontaneous bacterial peritonitis (SBP) is an important cause of mortality and morbidity in such patients with ascites. A polymorphonuclear (PMN) cell count $>250 / \mu 1$ in the ascitic fluid is the current gold standard for diagnosing SBP which is considered a subjective test. Early diagnosis of SBP although vital is difficult in these patients. Interleukin 6 is pro-inflammatory marker that increases earlier in bacterial infection than other inflammatory markers. This is crucial in cirrhotic patients to initiate treatment accordingly.

Objective: Evaluate the role of IL 6 together with other inflammatory markers in early diagnosis of SBP and as prognostic markers as well.

Patients and methods: The study was conducted on 60 cirrhotic patients with ascites divided into 2 groups. Group I included 30 cirrhotic patients with sterile ascites and group II, 30 patients with SBP. Liver profile, serum creatinine, serum sodium, ascitic IL6 , C-reactive protein, serum pro-calcitonin , and ascitic fluid analysis were done for all patients in both groups. Exclusion criteria included; acute infection, diabetes mellitus, coronary vascular disease, collagen vascular disease and any form of sepsis.

Results: Ascitic IL6 mean value was 2171.5(62.2 - 5000) and 342.5(146 - 2567) $\mathrm{pg} / \mathrm{ml}$ in groups I and II respectively which was significantly higher in group I than among group II patients $(\mathrm{P}<0.001)$. Furthermore, the mean s. procalcitonin was $0.8(0.4-1.1)$ and $0.4(0.04-0.7) \mathrm{ng} / \mathrm{ml}$ among groups In and II respectively and it was significantly higher among the patients with SBP $(\mathrm{P}<0.001)$. Diagnosis of SBP among patients with liver cirrhosis could be suggested when ascitic IL6 and serum procalcitonin are assessed at a cut-off values of $>780 \mathrm{pg} / \mathrm{ml}$ and $>0.4 \mathrm{ng} / \mathrm{ml}$ respectively.

Conclusion: Ascitic IL6 and serum procalcitonin can be used as a valuable surrogate serum marker for early diagnosis of SBP in cirrhotic patients.
\end{abstract}

Keywords: Spontaneous bacterial peritonitis (SBP), inflammatory markers, IL 6, highly sensitive $C$-reactive protein and procalcitonin

\section{INTRODUCTION}

B acterial infections are one of the deleterious complications in patients with cirrhosis as they carry high morbidity and mortality. Among these bacterial infections, spontaneous bacterial peritonitis (SBP), is the most common with an incidence ranging between 10 to $30 \%$ and around $32 \%$ mortality rate ref, $^{\cdot(1,2)}$
Spontaneous bacterial peritonitis is defined as an ascitic fluid infection in the absence of detectable intraabdominal surgically-treatable source. SBP is clinically suspected in patients with ascites due to advanced cirrhosis who develop symptoms such as fever, abdominal pain/ tenderness or diarrhea. With progression of sepsis it can cause altered mental status, paralytic ileus, hypotension, hypothermia and septic shock. Laboratory abnormalities are those of sepsis and are non-specific, they may show peripheral leukocytosis, metabolic acidosis, and azotemia.i About $13 \%$ of patients with SBP may lack signs of infection at time of $\operatorname{diagnosis}^{(2)}$

Spontaneous bacterial peritonitis is classified into: typical SBP with PMNL count $>250 / \mathrm{mm} 3$ and positive ascitic fluid culture without any evidence of external or intraabdominal source of infection or malignancy, culture-negative SBP with PMNL > $250 / \mathrm{mm} 3$ and a negative ascitic fluid culture, bacterascites with a positive ascitic fluid culture and an ascitic PMNL count $<250$ cells/mm3, sterile ascites with PMNL $<250 / \mathrm{mm} 3$ and a negative ascitic fluid culture. ${ }^{(2)}$

Spontaneous bacterial peritonitis results from derangement of the immune system together with impaired intestinal motility and reduced intestinal secretion of 
antibacterial polypeptides that end up in bacterial translocation in decompensated liver cirrhosis.ii During acute infections and inflammation as in the case of SBP, there is release of a number of pro-inflammatory and inflammatory mediators and cytokines which might have deleterious effect despite their role in host defense mechanisms.

Interleukin 6 is a pro-inflammatory cytokine produced by numerous cells, including leukocytes, adipocytes, endothelial cells, fibroblasts, and myocytes. It acts as a hepatocyte stimulatory factor to induce acute phase reactions. Acute phase reactants produced, whether positive such as C-reactive protein and fibrinogen or negative as albumin, indicate the presence of inflammation and correlate with its intensity. iii, iv, $\mathrm{v}$

Another pro-inflammatory marker is procalcitonin (PCT) which is a peptide precursor of calcitonin. It is secreted mainly by parafollicular thyroid cells. It is also secreted by neuroendocrine cells of the lung and intestine in response to sepsis, which makes it a good diagnostic and monitoring tool in such patients. It was found also that PCT level correlates with the severity and extent of infection. vi ,vii

\section{PATIENTS AND METHODS Study design:}

This study was conducted on 60 patients admitted at the internal and tropical medicine departments, Alexandria University hospitals suffering from Hepatitis C virus induced liver cirrhosis and ascites. The patients were classified according to presence or absence of SBP at time of admission into 2 groups:

Group 1: Included 30 patients with SBP based on PMNL $>250 / \mathrm{mm} 3$ with/without positive culture.

Group 2: Included 30 patients with sterile cirrhotic ascites (PMNL $<250 \mathrm{~mm} 3$ and a negative ascitic fluid culture). Patients with clinical evidence of infections other than SBP, malignancy, auto-immune diseases and on drugs affecting CRP level as statins and fibrates were excluded from the study. A written informed consent was obtained for all patients enrolled in the study.

About $6 \mathrm{ml}$ of venous blood were withdrawn aseptically into two vacutainer tubes as following: Four $\mathrm{ml}$ were

Table 1: Sex and age distribution of the studied groups delivered into a plain tube, to separate serum for routine investigation. Two $\mathrm{ml}$ were delivered into EDTA vacutainer tube to separate plasma for procalcitonin. Samples for PCT were separated and analyzed within four hours of the blood draw. If not, samples were stored at 2$8{ }^{\circ} \mathrm{C}$ for up to 24

Twenty $\mathrm{ml}$ of ascitic fluid were tapped into 2 sterile containers, the first one was for the physical, chemical and microscopic examination of ascitic fluid and the second one was for culture and sensitivity.

All study subjects were investigated for fasting blood sugar, 2-hours post prandial blood sugar, liver profile, renal function tests, and highly sensitive CRP. All routine investigations were measured by the Biosystems A25 Automated chemistry analyzer (Biosystems, Spain).

Serum sodium and potassium were measured using AVL 9180 Series Electrolyte Analyzers (Roche Diagnostics, USA). Procalcitonin was measured by Chemiluminescent assay (CLIA) on the ADVIACentaur® (Siemens, Germany).viii

IL6 was measured in ascitic fluid by Enzyme linked immunosorbent assay using Human IL-6 Quantikine ELISA Kit (R\&D, USA) according to the manufacturer instructions.ix

\section{STATISTICAL ANALYSIS OF THE DATA}

Data were fed to the computer and analyzed using IBM SPSS software package version 20.0. Comparisons between groups for categorical variables were assessed using Chi-square test. Mann Whitney test was used to compare two groups for abnormally distributed quantitative variables. While Student t-test was used for comparing the two studied groups for normally distributed quantitative variable. Significance of the obtained results was judged at the $5 \%$ level.

\section{RESULTS:}

Sixty patients with HCV induced liver cirrhosis and ascites were enrolled in this study. The cases of SBP (group I) were 30 of which $18(60 \%$ ) patients were men, mean age was $60 \pm 9.9$ years. Among the 30 other cases without SBP (group II); $18(60 \%)$ were males, the mean age was $57.3 \pm 10.2$ years. (Table 1$)$

\begin{tabular}{|c|c|c|c|c|}
\hline & $\begin{array}{l}\text { Group I } \\
(\mathbf{n}=\mathbf{3 0})\end{array}$ & $\begin{array}{l}\text { Group II } \\
(\mathbf{n}=\mathbf{3 0})\end{array}$ & $\begin{array}{l}\text { Test of } \\
\text { Sig. }\end{array}$ & $\mathbf{P}$ \\
\hline \multicolumn{5}{|l|}{ Sex no.(\%) } \\
\hline Male & $18(60 \%)$ & $18(60 \%)$ & \multirow{2}{*}{$\begin{array}{c}\chi^{2}= \\
0.000\end{array}$} & \multirow{2}{*}{1.000} \\
\hline Female & $12(40 \%)$ & $12(40 \%)$ & & \\
\hline Age (years) & $60 \pm 9.9$ & $57.3 \pm 10.2$ & $\mathrm{t}=1.042$ & 0.302 \\
\hline
\end{tabular}


Among group I, the mean serum albumin was $2.6 \pm 0.4$ $\mathrm{g} / \mathrm{dl}$, serum bilirubin was $1.9(0.4-6) \mathrm{mg} / \mathrm{dl}$, ALT ranged from 12 to $156 \mathrm{u} / \mathrm{l}$ with a mean $31.5 \mathrm{u} / \mathrm{l}$, mean AST was $34.5(29-156) \mathrm{u} / \mathrm{l}$, mean prothrombin time was $14.6 \pm 1.1$ sec with mean INR $1.3 \pm 0.1$. Regarding group II, the mean s. albumin was $2.7 \pm 0.3 \mathrm{~g} / \mathrm{dl}$, mean s. bilirubin was $1.3 \mathrm{mg} / \mathrm{dl}$ ranging from 0.5 to 2.3 , mean ALT and AST were $33.5 \mathrm{u} / \mathrm{l}$ for both, mean PT was $14.8 \pm 2.1$ seconds and mean INR $1.4 \pm 0.3$. Serum LDH was higher among group I, but with no significant difference. (Table 2)

Regarding the CBC findings, the mean $\mathrm{HB}$ was $11.9 \pm 1.4$ and $10.7 \pm 1.2 \mathrm{~g} / \mathrm{dl}$ among the patients in groups I and II respectively, it was significantly lower in group II than group I $(\mathrm{p}=0.001)$. The mean $\mathrm{WBC}$ was significantly higher among group I than group II $(\mathrm{P}<0.001)$, while platelets count was significantly higher in group I than group II ( $\mathrm{P}=0.023)$. (Table 3)

Table (4) showed the results of renal function tests, serum $\mathrm{Na}$ and $\mathrm{K}$ in the studied groups. The mean blood urea and serum creatinine in group I were 65 (32-195) and $1.5(0.7-4)$ $\mathrm{mg} / \mathrm{dl}$ respectively, while in group II blood urea and creatinine were 45(24-190) and 1.1(0.7-1.3) $\mathrm{mg} / \mathrm{dl}$ respectively.

Creatinine was significantly higher among group I than among group II $(\mathrm{P}=0.001)$.

The mean serum $\mathrm{Na}$ was $133.7 \pm 4.4$ and $133.5 \pm 3$ $\mathrm{mmol} / \mathrm{L}$ among groups I and II respectively, while mean serum $\mathrm{K}$ was $4.5(2.9-6)$ and $4.4(3-7) \mathrm{mmol} / \mathrm{L}$ in groups I and II respectively. No significant difference was found between both groups regarding serum $\mathrm{Na}$ and $\mathrm{K}$ $(\mathrm{P}=0.841)$.

Regarding the degree of ascites, 21 patients (70\%) had moderate ascites and 9 patients $(30 \%)$ had tense ascites among group I. In group II; 15 patients (50\%) had mild ascites, 6 patients $(20 \%)$ had moderate ascites and 9 patients $(30 \%)$ had tense ascites. Significant difference was detected between the two studied groups regarding the degree of ascites $(\mathrm{P}<0.001)$. (Table 5)

Table 2: Distribution of the studied cases according to the liver functions

\begin{tabular}{lcccc}
\hline & $\begin{array}{c}\text { Group I } \\
(\mathbf{n o = 3 0})\end{array}$ & $\begin{array}{c}\text { Group II } \\
(\mathbf{n o = 3 0})\end{array}$ & Test of sig. (t) & P \\
\hline Serum Albumin $(\mathrm{g} / \mathrm{dl})$ & $2.6 \pm 0.4$ & $2.7 \pm 0.3$ & 1.555 & 0.125 \\
\hline Serum bilirubin $(\mathrm{mg} / \mathrm{dl})$ & $1.9(0.4-6)$ & $1.3(0.5-2.3)$ & 351.0 & 0.141 \\
\hline ALT $(\mathrm{u} / \mathrm{l})$ & $31.5(12-156)$ & $33.5(10-67)$ & 447.0 & 0.965 \\
\hline AST $(\mathrm{u} / \mathrm{l})$ & $34.5(29-156)$ & $33.5(16-60)$ & 370.5 & 0.239 \\
\hline PT $(\mathrm{sec})$ & $14.6 \pm 1.1$ & $14.8 \pm 2.1$ & 0.570 & 0.572 \\
\hline INR & $1.3 \pm 0.1$ & $1.4 \pm 0.3$ & 1.771 & 0.085 \\
\hline Serum LDH $(\mathbf{m m o l} / \mathbf{l})$ & $381.5(213-480)$ & $320(120-394)$ & $\mathrm{U}=318.0$ & 0.051 \\
\hline
\end{tabular}

Table 3: Comparison between group I and group II according to CBC findings

\begin{tabular}{lcccc}
\hline & $\begin{array}{c}\text { Group I } \\
(\mathbf{n o = 3 0})\end{array}$ & $\begin{array}{c}\text { Group II } \\
(\mathbf{n o = 3 0})\end{array}$ & Test of sig. & P \\
\hline HB $(\mathbf{g} / \mathbf{d l})$ & $11.9 \pm 1.4$ & $10.7 \pm 1.2$ & $\mathrm{t}=3.483^{*}$ & $0.001^{*}$ \\
\hline WBCs $\left(\mathbf{x 1 0} \mathbf{3}^{*} \mathbf{m m}^{\mathbf{3}}\right)$ & $10.4 \pm 1.7$ & $5.5 \pm 1.7$ & $\mathrm{t}=11.435^{*}$ & $<0.001^{*}$ \\
\hline PLT $\left(\mathbf{x 1 0} \mathbf{m m}^{\mathbf{3}}\right)$ & $134(87-353)$ & $115(69-257)$ & $\mathrm{t}=297.0^{*}$ & $0.023^{*}$ \\
\hline
\end{tabular}

Table 4: Renal function tests, serum $\mathrm{Na}$ and $\mathrm{K}$ in the studied groups.

\begin{tabular}{ccccc}
\hline & $\begin{array}{c}\text { Group I } \\
(\mathbf{n o = 3 0})\end{array}$ & $\begin{array}{c}\text { Group II } \\
(\mathbf{n o = 3 0})\end{array}$ & Test of sig. & P \\
\hline Blood urea (mg/dl) & $65(32-195)$ & $45(24-190)$ & $\mathrm{U}=360.0$ & 0.182 \\
\hline Serum Creatinine (mg/d) & $1.5(0.7-4)$ & $1.1(0.7-1.3)$ & $\mathrm{U}=234.0^{*}$ & $0.001^{*}$ \\
\hline $\mathbf{N a}(\mathbf{m m o l} / \mathbf{L})$ & $133.7 \pm 4.4$ & $133.5 \pm 3$ & $\mathrm{t}=0.206$ & 0.838 \\
\hline K $(\mathbf{m m o l} / \mathbf{L})$ & $4.5(2.9-6)$ & $4.4(3-7)$ & $\mathrm{U}=436.5$ & 0.841 \\
\hline
\end{tabular}

Table 5: Distribution of the studied groups according to the degree of ascites

\begin{tabular}{|c|c|c|c|c|}
\hline Ascites (No (\%)) & $\begin{array}{l}\text { Group I } \\
(\text { no=30) }\end{array}$ & $\begin{array}{c}\text { Group II } \\
(\text { no=30) }\end{array}$ & Test of sig. & $\mathbf{P}$ \\
\hline Mild & $0(0 \%)$ & $15(50 \%)$ & \multirow{3}{*}{$\begin{array}{c}\chi^{2}= \\
23.333^{*}\end{array}$} & \multirow{3}{*}{$<0.001^{*}$} \\
\hline Moderate & $21(70 \%)$ & $6(20 \%)$ & & \\
\hline Tense & $9(30 \%)$ & $9(30 \%)$ & & \\
\hline
\end{tabular}


Using Child-Pugh classification, 21 (70\%) patients with SBP (group I)were Child B and $9(30 \%)$ patients were Child $\mathrm{C}$ (mean of the score was $8.9 \pm 1$ ). Among group II, 27 (90\%) patients were Child B and $3(10 \%)$ patients were Child C (mean of the score was $8.2 \pm 1.1$ ). Significant difference was detected between group I and group II regarding Child Pugh score $(\mathrm{P}=0.011)$. (Table 6)

Ascitic fluid analysis in both groups revealed the following: (Table 7)

The mean protein content in the ascitic fluid was $(2.2 \pm$ $0.6)$ and $(3.6 \pm 0.8) \mathrm{gm} / \mathrm{dl}$ in groups I and II respectively, it was significantly lower in group I than in group II $(\mathrm{P}<0.001)$

The mean ascitic glucose was (112.2 \pm 53$)$ and (104 \pm $27.9) \mathrm{mg} / \mathrm{dl}$ in groups I and II respectively. The mean LDH level was 272(50-550) and 54.5(20-140) U/L among groups I and II respectively which was significantly different $(\mathrm{P}<0.001)$. The mean ascitic $\mathrm{PMNL}$ was 300 (60-440) and $52.5(18-210)$ cell $/ \mathrm{mm}^{3}$ in groups I and II respectively, it was significantly higher in cases of SBP group I than in group II $(\mathrm{P}<0.001)$. There was also significant difference between groups I and II regarding ascitic fluid lymphocytes ( $\mathrm{P}=0.023)$.

The culture of ascitic fluid was positive in 24 patients $(80 \%)$ in group I, while it was positive in 3 patients $(10 \%)$ in group II which was significantly different $(\mathrm{P}<0.001)$.
Among the inflammatory markers used to diagnose patients with SBP was IL6 in ascitic fluid; its mean value was $2171.5(62.2-5000)$ and $342.5(146-2567) \mathrm{pg} / \mathrm{ml}$ in groups I and II respectively which was significantly different among the two groups $(\mathrm{U}=153) \quad(\mathrm{P}<0.001)$. (Table 8)

Furthermore, the mean serum procalcitonin was 0.8(0.41.1) and $0.4(0.04-0.7) \mathrm{ng} / \mathrm{ml}$ among the patients in groups I and II respectively and it was significantly higher in patients of SBP $(\mathrm{P}<0.001)$. (Table 8 and figure 1) Serum CRP was higher among cases of SBP in group I, but with no significant difference. (Table 8)

Receiver operating characteristic curves (ROC curves) of ascitic IL6 as well as serum procalcitonin were done to estimate the cutoff points at which SBP can be diagnosed. The ROC curve for ascitic IL6 was significant $(<0.001)$ $(\mathrm{AUC}=0.830)$ and showed that the cutoff point to diagnose SBP was $>780 \mathrm{pg} / \mathrm{ml}$, with sensitivity of $90 \%$, specificity of $80 \%$, positive predictive value of $81.8 \%$ and negative predictive value of $88.9 \%$. (Figure 2, Table 9)

The ROC curve for serum procalcitonin was significant $(<0.001)$ (AUC=0.875) and showed that the cutoff point to diagnose SBP was $>0.4 \mathrm{ng} / \mathrm{ml}$, with sensitivity of $90 \%$, specificity of $70 \%$, positive predictive value of $75 \%$ and negative predictive value of $87.5 \%$ ( Figure 3 , Table 10).

Table 6: Distribution of the studied groups according to Child Pugh score

\begin{tabular}{|c|c|c|c|c|}
\hline & $\begin{array}{l}\text { Group I } \\
(\text { no= }=30)\end{array}$ & $\begin{array}{c}\text { Group II } \\
(\text { no= }=30)\end{array}$ & Test of sig. & $\mathbf{P}$ \\
\hline Child score (No (\%)) & $8.9 \pm 1$ & $8.2 \pm 1.1$ & $\mathrm{t}=2.633^{*}$ & $0.011^{*}$ \\
\hline A & $0(0 \%)$ & $0(0 \%)$ & \multirow{3}{*}{$\begin{array}{c}\chi^{2}= \\
3.750\end{array}$} & \multirow{3}{*}{0.053} \\
\hline B & $21(70 \%)$ & $27(90 \%)$ & & \\
\hline $\mathrm{C}$ & $9(30 \%)$ & $3(10 \%)$ & & \\
\hline
\end{tabular}

Table 7: Different lab parameters and culture of ascitic fluid in the studied groups

\begin{tabular}{lcccc}
\hline & $\begin{array}{c}\text { Group I } \\
(\mathbf{n o = 3 0})\end{array}$ & $\begin{array}{c}\text { Group II } \\
(\mathbf{n o = 3 0})\end{array}$ & Test of sig. & P \\
\hline Ascitic Protein $(\mathrm{g} / \mathrm{dl})$ & $2.2 \pm 0.6$ & $3.6 \pm 0.8$ & $\mathrm{t}=7.806$ & $<0.001^{*}$ \\
\hline Ascitic Glucose $(\mathrm{mg} / \mathrm{dl})$ & $112.2 \pm 53$ & $104 \pm 27.9$ & $\mathrm{t}=0.750$ & 0.457 \\
\hline Ascitic LDH $(\mathrm{U} / \mathrm{L})$ & $272(50-550)$ & $54.5(20-140)$ & $\mathrm{U}=126.0^{*}$ & $<0.001^{*}$ \\
\hline Ascitic PMNL $\left(\mathrm{cells} / \mathrm{mm}^{3}\right)$ & $300(60-440)$ & $52.5(18-210)$ & $\mathrm{U}=45.0^{*}$ & $<0.001^{*}$ \\
\hline Ascitic RBC $\left(\mathrm{cells} / \mathrm{mm}^{3}\right)$ & $38.5(12-2250)$ & $40.5(10-140)$ & $\mathrm{U}=355.5$ & 0.162 \\
\hline Ascitic Lymphocytes $\left(\mathrm{cells} / \mathrm{mm}^{3}\right)$ & $77.5(12-400)$ & $34.5(10-160)$ & $\mathrm{U}=297.0^{*}$ & $0.023^{*}$ \\
\hline Ascitic Culture & & & & $\chi^{2}=$ \\
\hline Positive & $24(80 \%)$ & $3(10 \%)$ & $29.697^{*}$ & $<0.001^{*}$ \\
\hline
\end{tabular}


Table 8: Comparison between the studied groups according to some Inflammatory markers

\begin{tabular}{|l|c|c|c|c|}
\hline & $\begin{array}{c}\text { Group I } \\
(\mathbf{n o = 3 0})\end{array}$ & $\begin{array}{c}\text { Group II } \\
(\mathbf{n o = 3 0})\end{array}$ & Test of sig. & P \\
\hline Ascitic IL6 $(\mathrm{pg} / \mathrm{ml})$ & $2171.5(62.2-5000)$ & $342.5(146-2567)$ & $\mathrm{U}=153.0^{*}$ & $<0.001^{*}$ \\
\hline Serum procalcitonin $(\mathbf{n g} / \mathbf{m l})$ & $0.8(0.4-1.1)$ & $0.4(0.04-0.7)$ & $\mathrm{U}=112.5$ & $<0.001^{*}$ \\
\hline Serum CRP $(\mathbf{m g} / \mathbf{l})$ & $68(32-98)$ & $56.5(12-83)$ & $\mathrm{U}=337.5$ & 0.096 \\
\hline
\end{tabular}

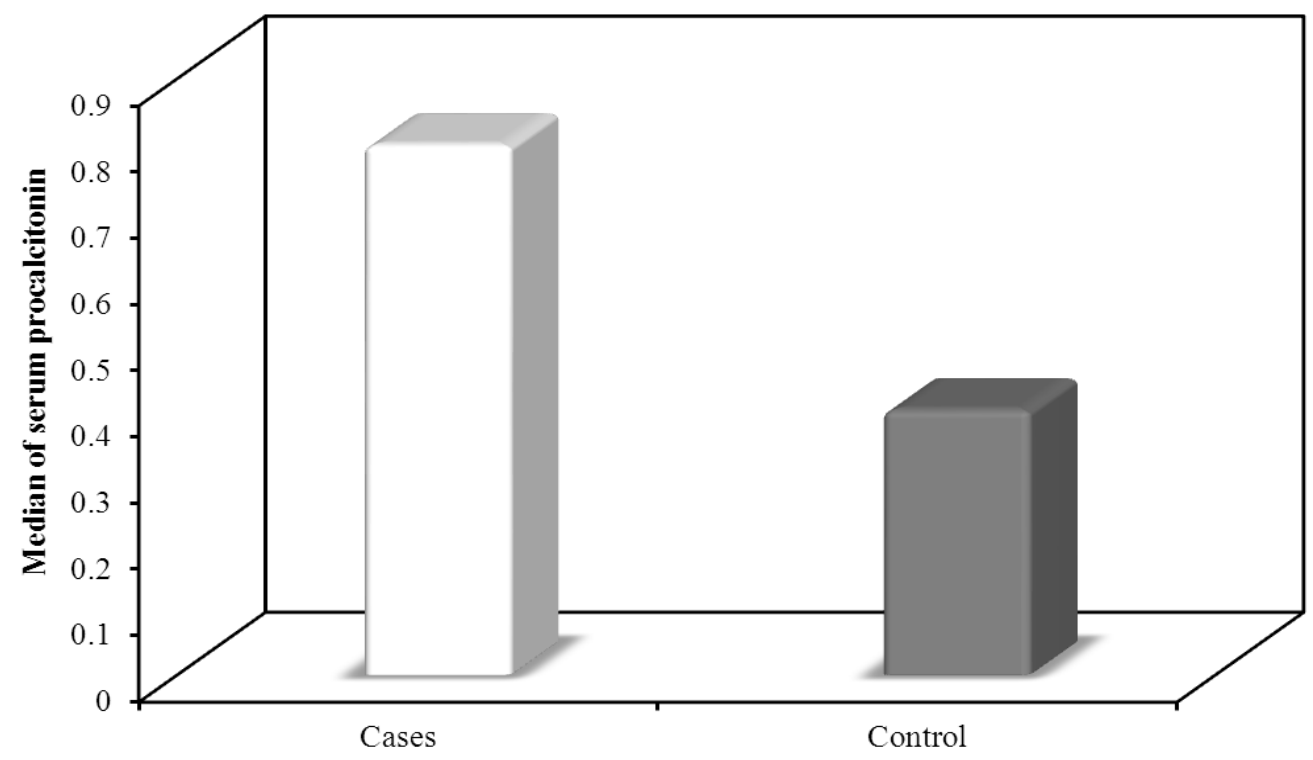

Figure (1): Comparison between the two studied groups according to Serum procalcitonin (ng/ml)

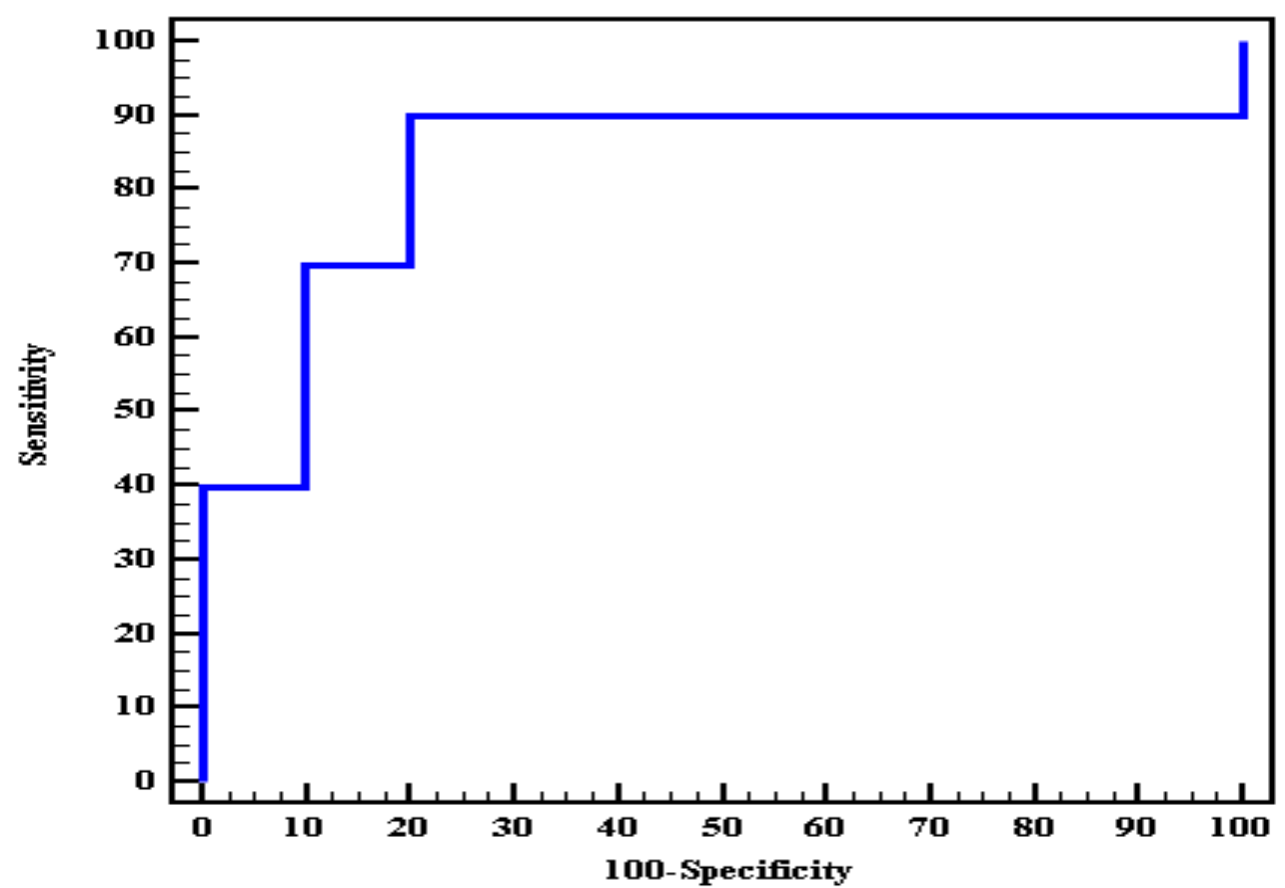

Figure (2):ROC curve for ascitic IL6 to detect SBP patients group I from group II 
Table 9: Accuracy of IL6 to detect SBP.

\begin{tabular}{|c|c|c|c|c|c|c|c|c|c|}
\hline & \multirow{2}{*}{$\mathbf{A U C}$} & \multirow{2}{*}{$\mathbf{p}$} & \multicolumn{2}{|c|}{$95 \%$ C.I } & \multirow{2}{*}{ 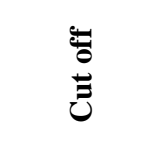 } & \multirow{2}{*}{ 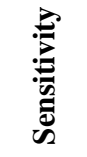 } & \multirow{2}{*}{ 莺 } & \multirow{2}{*}{ 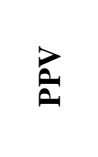 } & \multirow{2}{*}{$\frac{\vec{z}}{\mathbf{z}}$} \\
\hline & & & $\mathbf{L L}$ & $\mathbf{U L}$ & & & & & \\
\hline a.IL6 & $0.830^{*}$ & $<0.001^{*}$ & 0.713 & 0.947 & $>780 \mathrm{pg} / \mathrm{ml}$ & $90 . \%$ & $80.0 \%$ & $81.8 \%$ & $88.9 \%$ \\
\hline
\end{tabular}

CI: Confidence Intervals

LL: Lower limit

NPV: Negative predictive value

*: Statistically significant at $\mathrm{p} \leq 0.05$
UL: Upper Limit

PPV: Positive predictive value

Table 10: Accuracy of serum procalcitonin to detect SBP

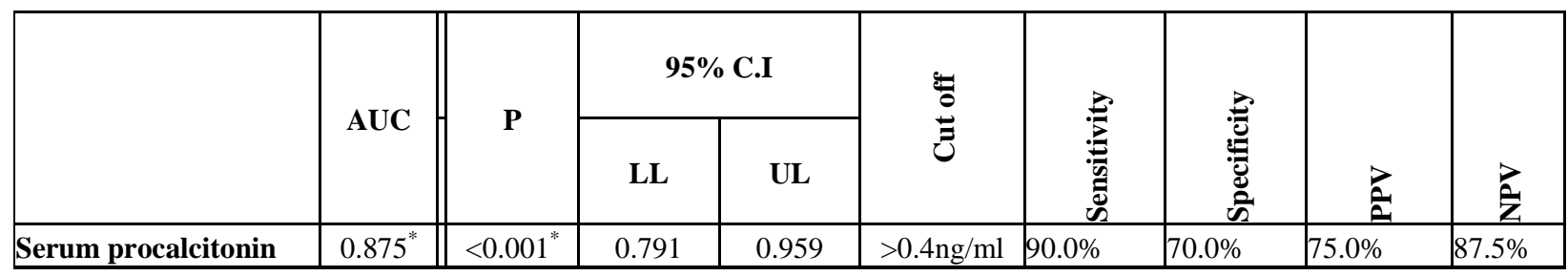

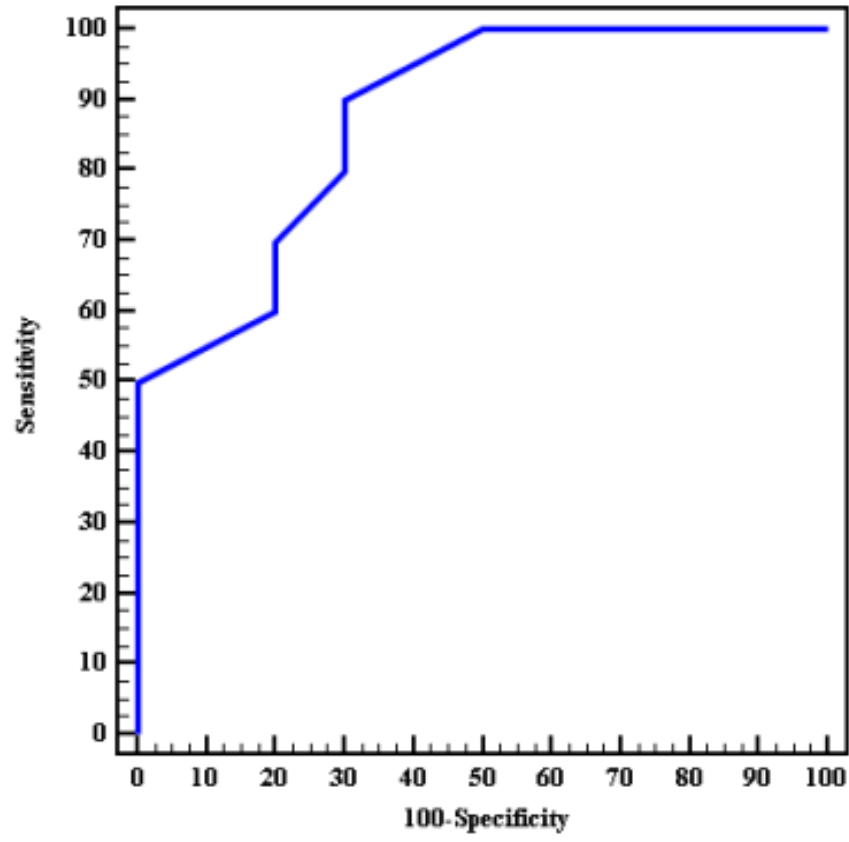

Figure (3): ROC curve for serum procalcitonin to detect SBP.

\section{DISCUSSION}

Liver cirrhosis carries a high risk of sepsis because of impairment of both innate and humoral immunity together with bacterial translocation resulting from defective intestinal mucosal barriers. Sepsis in such patients carries very bad prognosis as a consequence of release of inflammatory mediators that may lead to multiorgan dysfunction. This necessitates rapid diagnosis and treatment of SBP. Serum inflammatory markers as PCT and CRP together can be used as rapid diagnostic tool in such patients. ${ }^{\mathrm{x}}$

PCT was first discovered in 1975 as a precursor for calcitonin hormone produced by parafollicular cells in thyroid gland. Calcitonin is involved in calcium and phosphorus homeostasis. In healthy individuals all PCT is converted into calcitonin and is not released into the circulation. During sepsis, inflammatory response results in production and release of PCT. It is either produced by a direct or indirect mechanism. The direct mechanism involves induction of hepatocytes and peripheral blood monocytes by toxic metabolites and bacteria lipopolysaccharides. The indirect one is activated by the release of inflammatory mediators such as IL6. ${ }^{\mathrm{x} x \mathrm{xi}}$

Interleukin 6 , a pro-inflammatory cytokine secreted by monocytes and macrophages, requires signal transduction by STAT3/ Jak-kinase pathway to upregulate acute-phase genes in the liver. ${ }^{\text {xii }}$

In our study we examined the role of ascitic IL 6 together with other acute phase reactants including Hs-CRP and procalcitonin in early diagnosis of SBP in sixty cirrhotic patients. Twenty percent of the patients (6/30) in group I had culture-negative SBP versus $90 \%$ (27/30) patients of group II, and all of the culture-positive SBP patients $(80 \%, 24 / 30)$ had E. coli positive cultures. 
In our study, there was no statistical difference between both groups as regards liver enzymes ( AST and ALT) and serum LDH. Serum LDH $\{381.5(213$ - 480) vs $320(120$ - 394) $\} \mathrm{mmol} / \mathrm{l}$, level was higher in patients in group I compared to patients with sterile cirrhotic ascites in group II, but with no statistical significance, $\mathrm{p}<0.051$.

We found that serum CRP $\{68(32$ - 98) vs 56.5(12 83) $\mathrm{mg} / \mathrm{l}$ level was higher in patients in group I than their levels in patients with sterile cirrhotic ascites in group II, but with no statistical significance, $\mathrm{p}<0.096$. On the other hand, serum PCT showed statistically significant difference between the two groups being higher in group I compared to patients in group II, $\mathrm{p}<0.001$. The mean serum PCT was $0.8(0.4-1.1)$ and $0.4(0.04-0.7) \mathrm{ng} / \mathrm{ml}$ in groups I and II respectively.

As regards ascitic fluid parameters, significant difference was detected between the two studied groups regarding the degree of ascites. In group I, none of the cases had mild ascites while $70 \%$ patients had moderate ascites and $30 \%$ had tense ascites. In group II , half of the cases had mild ascites, $20 \%$ patients had moderate and the remaining $30 \%$ had tense ascites.

Ascitic fluid PMNL was significantly higher in patients with SBP in group I than group II. The mean ascitic fluid protein was much lower in group I $(2.2 \pm 0.6) \mathrm{g} / \mathrm{dl}$ a than group II $(3.6 \pm 0.8) \mathrm{g} / \mathrm{dl}$. Also, we found that there was a statistically significant increase of the level of ascitic IL6 in group I, $2171.5 \mathrm{pg} / \mathrm{dl}(62.2-5000)$, compared to patients in group II, $342.5(146-2567) \mathrm{pg} / \mathrm{dl}, p<0.001$.

The cutoff points for PCT and IL6 to diagnose SBP were $>0.4 \mathrm{ng} / \mathrm{ml}$ and $>780 \mathrm{pg} / \mathrm{ml}$ respectively, with sensitivity of $90 \%$ for each of them.

In literature there is controversy on the diagnostic value of PCT and CRP in SBP in end stage liver disease. Two meta-analyses, one included three studies by $\mathrm{Su}$ et al xiii and the other included seven studies ${ }^{\text {xiv }}$, both found moderate to high accuracy of PCT to rule in or rule out SBP. Our results are comparable to the results reported by Navasa et $a l^{\mathrm{xv}}$ and Suliman et al ${ }^{\mathrm{xvi}}$ who reported that IL6 both in serum and ascitic fluid was higher in SBP compared to sterile ascites. The latter also concluded that serum and ascitic IL 6 correlated with the development of renal impairment and Child-Pugh class in patients with SBP. Another finding reported by Suliman et al was the decline in ascitic IL6 following treatment of SBP.

One study conducted by Ahmed et al found similar findings as our study. It reported that there was significant increase in serum and ascitic IL6 in SBP compared to sterile ascites (553 [432-956] ng/mL vs 195 [95-347] $\mathrm{ng} / \mathrm{mL} ; \mathrm{p}<0.001)$. The study also reported statistically significant increase in serum PCT in SBP versus non-SBP. A cutoff value of $0.94 \mathrm{ng} / \mathrm{mL}$, serum PCT had a diagnostic sensitivity of $94.3 \%$ and specificity $91.8 \%$ for detecting SBP. In our study, the cutoff value of PCT was lower, $>0.4 \mathrm{ng} / \mathrm{ml}$, with $90 \%$ sensitivity and $70 \%$ specificity. ${ }^{\text {xvi }}$

On the other hand, Magdalena et al found no difference in serum and ascitic PCT levels among SBP and non SBP patients which contradicts our results. ${ }^{\text {xviii }}$

In conclusion, the combined use of serum PCT, CRP and ascitic IL6 can be used for early diagnosis of patients with SBP, although further studies with larger number of patients are needed to confirm these findings

\section{REFERENCES}

1. De Mattos AA, Costabeber AM, Lionço LC and Tovo CV. Multi-resistant bacteria in spontaneous bacterial peritonitis: A new step in management? World Journal of Gastroenterology ,2014;20(39):14079-86.

doi:10.3748/wjg.v20.i39.14079.

2. Bonnel AR, Bunchorntavakul $\mathrm{C}$ and Reddy KR. Immune dysfunction and infections in patients with cirrhosis. Clin Gastroenterol Hepatol. 2011; 9:727-38

3. Such J and Runyon BA. Spontaneous bacterial peritonitis. Clin Infect Dis 1998; 27:669.

4. Runyon BA. Monomicrobial non-neutrocytic bacterascites: a variant of spontaneous bacterial peritonitis. Hepatology $1990 ; 12: 710$.

5. Khayyal AE, Helmy A , Hussein M, et al . Serum Interleukin 22 Levels in Predicting spontaneous bacterial peritonitis in hepatitis $\mathrm{C}$ virus related liver Cirrhosis in comparison with Serum Total Leukocytic count and C Reactive Protein in Egyptian Patients. International Journal of Advanced Research (2015), Volume 3, Issue 8, $764-773$

6. Li YT, Yu CB, Huang GP et Pathogen profile and drug resistance analysis of spontaneous peritonitis in cirrhotic patients. World J Gastroenterol. 2015 Sep 28;21(36): 10409- 17.

7. Bennermo M, Held C, Stemme S,et al. Genetic Predisposition of the Interleukin-6 Response to Inflammation: Implications for a Variety of Major Diseases. Clinical Chemistry 50, No. 11, 2004

8. Gabay C. Interleukin-6 and chronic inflammation. Arthritis Research \& Therapy2006,8(Supp1 2):S3.

9. Maggio M, Guralnik JM, Longo DL, et al. in Aging and Chronic Disease: A Magnificent Pathway . J Gerontol A Biol Sci Med Sci (2006) 61 (6): 575-584.

10. Vijayan A, Ravindran S, Saikant R, Lakshmi L, et al. Procalcitonin: a promising diagnostic marker for sepsis and antibiotic therapy. J Intensive Care. 2017; 5: 51

11. Taylor RR, Jones A, Kelly S et al. A Review of the Value of Procalcitonin as a Marker of Infection. Cureus. 2017 Apr; 9(4): e1148 hard Taylor,

12. Sanders RJ, Schoorl M, Dekker E, Snijders D, Boersma WG, Ten Boekel E. Evaluation of A New Procalcitonin Assay for the Siemens ADVIA Centaur ${ }^{\circledR}$ with the Established Method on the BRAHMS Kryptor. Clin. Lab. 2011;57:415-20.

13. Lane D, Matte I,Rancourt C, and Piché A. Prognostic significance of IL-6 and IL-8 ascites levels in ovarian cancer patients. BMC Cancer 2011; 11: 210. 
14. Cai ZH, Fan C, Zheng ZU, Zhang X ,et al. Measurement of serum procalcitonin levels for the early diagnosis of spontaneous bacterial peritonitis in patients with decompensated liver cirrhosis. BMC Infectious Diseases (2015) 15:55

15. Vijayan et al. Journal of Intensive Care (2017) 5:51 Procalcitonin: a promising diagnostic marker for sepsis and antibiotic therapy Ashitha L. Vijayan, Vanimaya, Shilpa Ravindran, R. Saikant, S. Lakshmi, R. Kartik and Manoj. G

16. Liuzzi JP, Lichten JA, Rivera S, et al. Interleukin-6 regulates the zinc transporter Zip14 in liver and contributes to the hypozincemia of the acute-phase response. PNAS May 10, 2005 vol. 102 no. $196843-6848$

17. Su DH, Zhuo $\mathrm{C}$, Liao $\mathrm{K}$, et al. Value of serum procalcitonin levels in predicting spontaneous bacterial peritonitis. Hepatogastroenterology. 2013 Jun; 60(124): 641-6

18. Yang Y, Li L, Qu C, Zeng B, et al. A Meta-analysis: Diagnostic Accuracy of Serum Procalcitonin for Spontaneous
Bacterial Peritonitis Due to End-stage Liver Disease. Medicine (Baltimore). 2015 Dec; 94(49): e2077

19. Navasa M, Follo A, Filella X, et al. Tumor necrosis factor and interleukin-6 in spontaneous bacterial peritonitis in cirrhosis: relationship with the development of renal impairment and mortality. Hepatology. 1998; 27: 1227-32.

20. Suliman AM, Khalil FM, Alkindi SA, et al. Tumor necrosis factor- $\alpha$ and interleukin- 6 in cirrhotic patients with spontaneous bacterial peritonitis. World J Gastrointest Pathophysiol. Oct 15, 2012; 3(5): 92-8

21. Ahmed A, Nasser M, Dina El, Rania E, Rasha E, Sherif E, et al. Ascitic Fluid Calprotectin and Serum Procalcitonin as Accurate Diagnostic Markers for Spontaneous Bacterial Peritonitis. Gut and Liver, Vol. 10, No. 4, July 2016, pp. 624-31

22. Magdalena L, Marek H, Krzys G, Ewa ND et al. Procalcitonin and macrophage inflammatory protein-1 beta (MIP-1 $\beta$ ) in serum and peritoneal fluid of patients with decompensated cirrhosis and spontaneous bacterial peritonitis. Advances in Medical Sciences, Vol. 59, Issue 1, March 2014, 52-6. 
